Article

\title{
Energy and Exergy Analysis of Sensible Thermal Energy Storage-Hot Water Tank for a Large CHP Plant in Poland ${ }^{\dagger}$
}

\author{
Ryszard Zwierzchowski ${ }^{1, *}$ and Marcin Wołowicz ${ }^{2, *}$ (D)
}

1 Department of District Heating and Gas Engineering, Faculty of Building Services, Hydro and Environmental Engineering, Warsaw University of Technology, 00-653 Warsaw, Poland

2 Institute of Heat Engineering, Faculty of Power and Aeronautical Engineering, Warsaw University of Technology, 00-665 Warsaw, Poland

* Correspondence: ryszard.zwierzchowski@pw.edu.pl (R.Z.); marcin.wolowicz@pw.edu.pl (M.W.)

+ This paper is an extended version of paper: Improvement of operation of steam cushion system for sensible thermal energy storage published in E3S Web of Conferences 116, 00107 (2019), International Conference on Advances in Energy Systems and Environmental Engineering (ASEE19), Wroclaw, Poland, 9-12 June 2019, https://doi.org/10.1051/e3sconf/201911600107.

Received: 15 August 2020; Accepted: 14 September 2020; Published: 16 September 2020

\begin{abstract}
The paper contains a simplified energy and exergy analysis of pumps and pipelines system integrated with Thermal Energy Storage (TES). The analysis was performed for a combined heat and power plant (CHP) supplying heat to the District Heating System (DHS). The energy and exergy efficiency for the Block Part of the Siekierki CHP Plant in Warsaw was estimated. CHP Plant Siekierki is the largest CHP plant in Poland and the second largest in Europe. The energy and exergy analysis was executed for the three different values of ambient temperature. It is according to operation of the plant in different seasons: winter season (the lowest ambient temperature $T_{e x}=-20^{\circ} \mathrm{C}$, i.e., design point conditions), the intermediate season (average ambient temperature $T_{e x}=1{ }^{\circ} \mathrm{C}$ ), and summer (average ambient temperature $T_{e x}=15^{\circ} \mathrm{C}$ ). The presented results of the analysis make it possible to identify the places of the greatest exergy destruction in the pumps and pipelines system with TES, and thus give the opportunity to take necessary improvement actions. Detailed results of the energy-exergy analysis show that both the energy consumption and the rate of exergy destruction in relation to the operation of the pumps and pipelines system of the CHP plant with TES for the tank charging and discharging processes are low.
\end{abstract}

Keywords: district heating system; combined heat and power; sensible thermal energy storage; hot water tank; energy and exergy analysis

\section{Introduction}

Nowadays, heat production for heating or domestic hot water is carried out in various ways. The heat can be produced locally, e.g., by gas or electric heaters, biomass boilers [1-3], etc., applicable to individual buildings or apartments $[4,5]$. Heat can also be produced ecologically using renewable energy sources [6]. Examples of this are solar collectors [7,8] and geothermal sources [9-14]. Heat can be also produced on a large scale, e.g., for a whole city (so called District Heating System-DHS) [15-19]. For this purpose, district heating plants (DHP) or combined heat and power plants $(\mathrm{CHP})$ producing electricity and heat in the so-called cogeneration are used.

Heat storage is an important aspect in the functioning of today's energy sector. This is related, inter alia, to the dynamic development of renewable energy, and hence to the uneven generation of electricity in relation to the demand. Heat is a by-product in the functioning of large power plants 
with condensing turbines or a commercial product in the case of combined heat and power generation (CHP). The production of heat in these sources is directly proportional to the production of electricity. An important parameter in CHP power plants is the "power-to-heat ratio". This coefficient determines the proportion of electricity to heat generated in a single CHP system. Of course, this coefficient is not constant but in the range of operation of most cogeneration units does not change much. Observing the cogeneration units operating in Poland, it can be seen that in the load range of $70-100 \%$, the change in this factor is small. It can therefore be assumed that in the useful range of a cogeneration unit operation, the production of electricity is directly related to the production of heat. There are large discrepancies in the demand for electricity and heat in the case of CHP operation. Therefore, it seems advisable to store either electricity or heat. Storing electricity is quite difficult and expensive on a large scale. The electricity can be easily sold to the grid making the use of a storage system unfavorable. The same cannot be said for the sale of heat as it is only transported locally. Moreover, its sale is closely related to the order carried out by the operator of a DHS or an industrial plant (in the case when heat can be sold for technological processes). Therefore, CHP plants began to invest in heat storages [15-19].

Due to their age, heating systems in Poland are currently undergoing extensive modernization. Mostly, the scope of modernization related to the generation and distribution of heat in the district heating system does not include pumping systems and pipelines located in energy sources or is carried out in a limited manner. In Polish district heating plants and CHP plants, pumping and pipeline systems are characterized by high energy consumption by devices installed in them, e.g., pumps, and also by flow losses through pipelines. The system is also not adapted to changing working conditions. The current modernization activities consist mainly in an attempt to reduce losses in pumping systems and pipelines, increasing their efficiency and availability. According to the authors of this article, all currently undertaken actions to modernize the above-mentioned systems, both in heating plants and in combined heat and power plants, should also take into account the introduction of Thermal Energy Storage (TES).

The water TES, known as heat accumulators, is commonplace in Denmark, Sweden, and Finland. They are also in use in other EU countries such as Austria, Italy, and Germany. It is difficult to establish an exact quantity of the installed capacity of the thermal energy storage projects worldwide. In the Nordic countries there were more than 100 heat storage projects at the end of 20th Century, most of them smaller than $2500 \mathrm{~m}^{3}$.

The intensive process of implementation of TES for DHS is presently observed in EU countries, but the TES market varies considerably, depending on the application fields and regions [20-23]. Some projects with thermal energy storage in Europe can be tracked with the Interactive Thermal Energy Storage Map [24].

Due to large differences between the supply and demand for energy, these discrepancies should be corrected. One of the best technologies currently used for this purpose is thermal energy storage. These systems contain a temporary medium that is responsible for high or low temperature storage depending on the needs and subsequent use [25]. Usually the energy storage system consists of a tank with all auxiliary equipment like a cushion system [26], storage medium, and devices responsible for the appropriate inlet and outlet conditions. The energy in the storage system is stored by increasing the temperature of the storage medium. The amount of energy stored is proportional to the temperature difference between the inlet and outlet of the reservoir, mass (volume), and heat capacity $[27,28]$.

Connecting TES to district heating system is treated as a quite new technology in the Polish district heating sector. This technology can improve the operational conditions of district heating systems. This results, inter alia, in a reduction of heat and electricity production costs, reduction of emission of pollutants to the atmosphere, and increasing energy security for consumers $[29,30]$.

In this paper energy and exergy analysis was performed for the whole hydraulic system of the CHP plant before and after implementation of the TES system. Additionally, the analysis was performed for the heating season (the highest outside temperature $T_{e x}=-20{ }^{\circ} \mathrm{C}$, i.e., calculating conditions), 
intermediate season (average temperature $T_{e x}=1{ }^{\circ} \mathrm{C}$ ), and summer season (average temperature $T_{e x}=$ $15^{\circ} \mathrm{C}$ ) using hourly operational data.

Such detailed analysis of implementation of the TES to the CHP plant and DHS is quite unique and can be considered as novel. This approach offers real conclusions resulting from energy and exergy analysis for future investors to furnish CHP plants with a TES system.

\section{System Description}

Energy and exergy analysis was performed for the Blocks Part of CHP plant Siekierki in Warsaw. CHP Plant Siekierki is the largest CHP plant in Poland and the second largest in Europe. The heating capacity of this plant is $2078 \mathrm{MW}_{\text {th }}$ whereas electrical capacity is $622 \mathrm{MW}_{\mathrm{el}}$. CHP plant Siekierki was launched in 1961. It consists of:

- Collector Part-the boilers supply a common steam collector from which the steam is directed to the turbines (number of boilers-4, number of turbines-5, electrical capacity-170 $\mathrm{MW}_{\mathrm{el}}$ ).

- Blocks Part-each block consists of its own boiler and its own turbine (number of blocks-3, electrical capacity-110 $\mathrm{MW}_{\mathrm{el}}$ each, heating capacity-175 $\mathrm{MW}_{\text {th }}$ each).

- Condensing turbine with steam extraction (electrical capacity-125 $\mathrm{MW}_{\mathrm{e}}$ ).

- Water boilers (number of boilers-6, total heating capacity-884 $\mathrm{MW}_{\mathrm{th}}$ ).

The Blocks Part of the Siekierki Combined Heat and Power Plant consists of base load units. During the heating season, all blocks work as basic units in continuous mode. Only one heating block is in operation in summer. This is due to the much lower heat demand. Heat is only needed to provide domestic hot water. When the ambient temperature drops below zero, the collector part is introduced to operation. When the temperature drops below $-15^{\circ} \mathrm{C}$, the water boilers are started. They are considered as a peak load boilers. Some cogeneration units are also put into operation when heat demand is low or does not exist. This takes place when the electricity demand is high or electricity prices are profitable. The decisive factor here is the economic calculation.

Figure 1 shows a simplified layout of CHP plant Siekierki. The CHP plant is connected to the DHS. The main piping lines indicated in the Figure 1 as $\mathrm{O}, \mathrm{C}, \mathrm{L}$, and $\mathrm{U}$ are responsible for supplying hot water to the DHS (top of the figure) and collecting cold water coming back (return) from DHS (bottom of the figure). The pumps responsible for return water are indicated as RP, pumps supplying water to the DHS are indicated as SP, water boilers B, and network water heaters XB or XC.

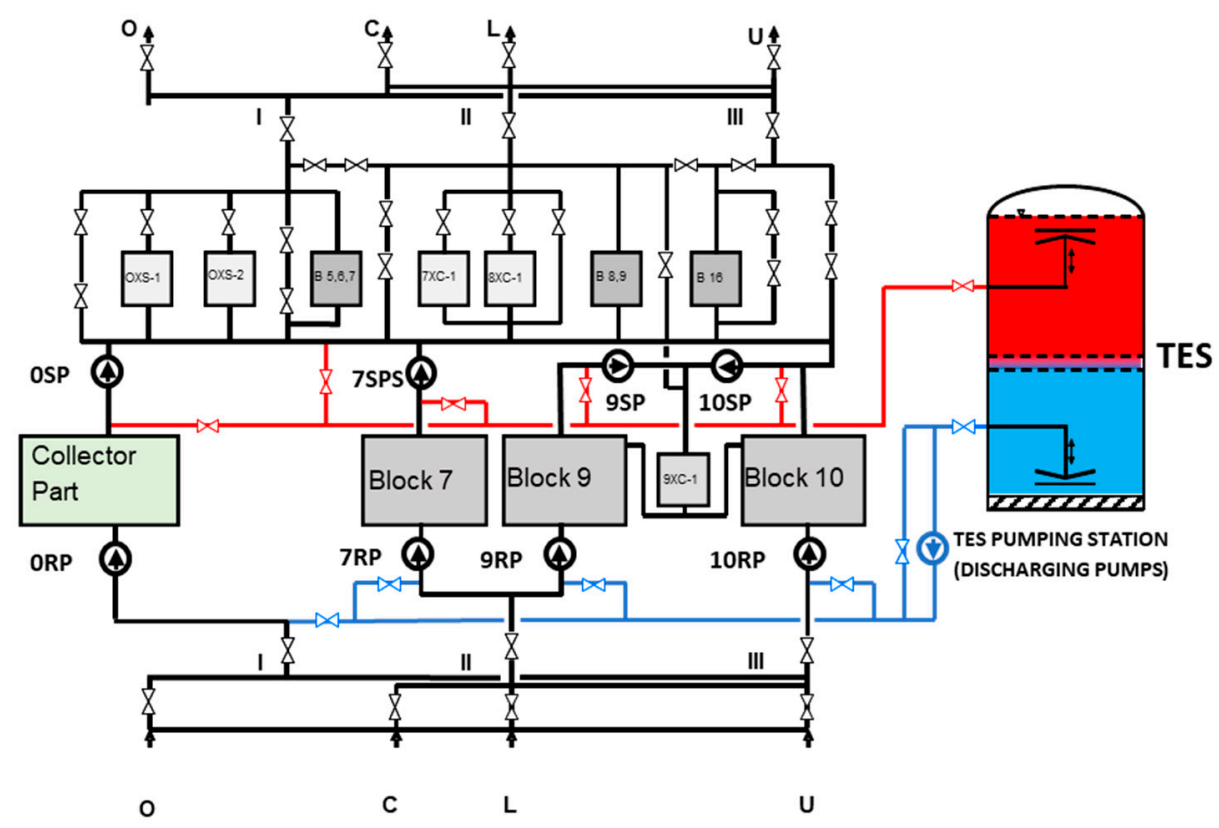

Figure 1. Simplified layout of the analyzed plant—combined heat and power plant (CHP) plant Siekierki. 
TES at the Siekierki CHP plant was put into operation in March 2009. Its design process started in 2007 and it was built in 2008. Its design is pressure-free tank. The TES was integrated with the DHS system by Discharging Pumps (DP). A steam cushion system has been used to prevent oxygen absorption by the water in the reservoir. Table 1.

The TES tank is shown in Figure 2 and the basic technical parameters of the TES are presented in

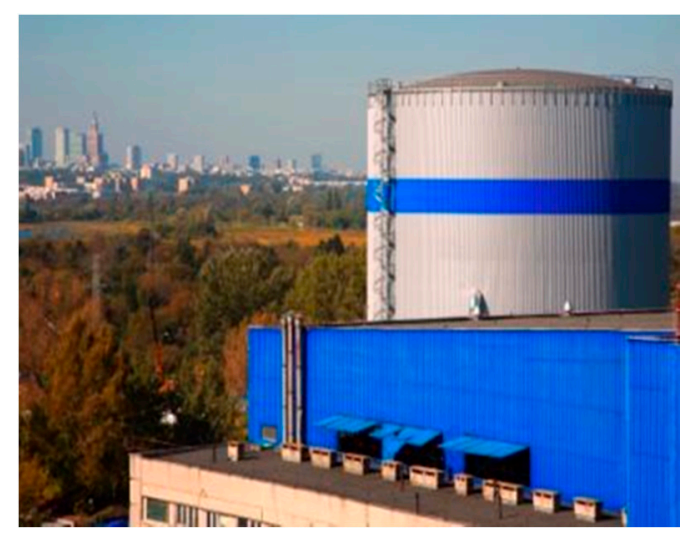

Figure 2. View of the TES tank in Warsaw CHP plant Siekierki.

Table 1. Basic technical parameters of Thermal Energy Storage (TES) in CHP plant Siekierki.

\begin{tabular}{ccc}
\hline Parameter & Value & Unit \\
\hline Total volume of the tank & 30,400 & $\mathrm{~m}^{3}$ \\
Diameter of the tank & 30 & $\mathrm{~m}$ \\
Height of shell of the tank & 43 & $\mathrm{~m}$ \\
Radius of room dome & 45 & $\mathrm{~m}$ \\
Insulation thickness & 0.5 & $\mathrm{~m}$ \\
Charging/discharging flow rate & 1250 & $\mathrm{~kg} / \mathrm{s}$ \\
Temperature of stored water & $98 / 40$ & ${ }^{\circ} \mathrm{C}$ \\
Total mass of the tank & 53,000 & $\mathrm{~kg}$ \\
\hline
\end{tabular}

\section{Materials and Methods}

Energy and exergy analysis was undertaken for three different operation variants for the Blocks Part of the CHP plant [31]:

- operation without TES,

- operation with TES-charging process,

- operation with TES-discharging process.

For all three operation variants the calculations for three representative values of outside temperatures were provided, i.e., $T_{e x}=-20{ }^{\circ} \mathrm{C}$-calculated temperature for the District Heating System in this region of Poland, $T_{e x}=1{ }^{\circ} \mathrm{C}$-temperature close to the average temperature for the heating season, $T_{e x}=15^{\circ} \mathrm{C}$-average temperature during the summer season.

The efficiency levels of the pumps in the system are set as below:

- Return Pumps- $\eta_{\mathrm{RP}}=80 \%$,

- Supply Pumps- $-\eta_{\mathrm{SP}}=82 \%$,

- Discharging Pumps (TES pumps) $-\eta_{D P}=90 \%$.

As input data for the calculations, operating parameters were collected from the existing plant (CHP plant Siekierki Warsaw). The data are hourly average taken from the DCS system for the period of 2 years before the TES installation and for 2 years after the installation. Data were measured 
and collected from characteristic CHP plant points which are indicated as numbers $1-7$ presented in Figures 3-5. The parameters that were measured are as follows: temperatures, flows, and pressures (return and supply water). The remaining quantities necessary for energy and exergy analysis were calculated.

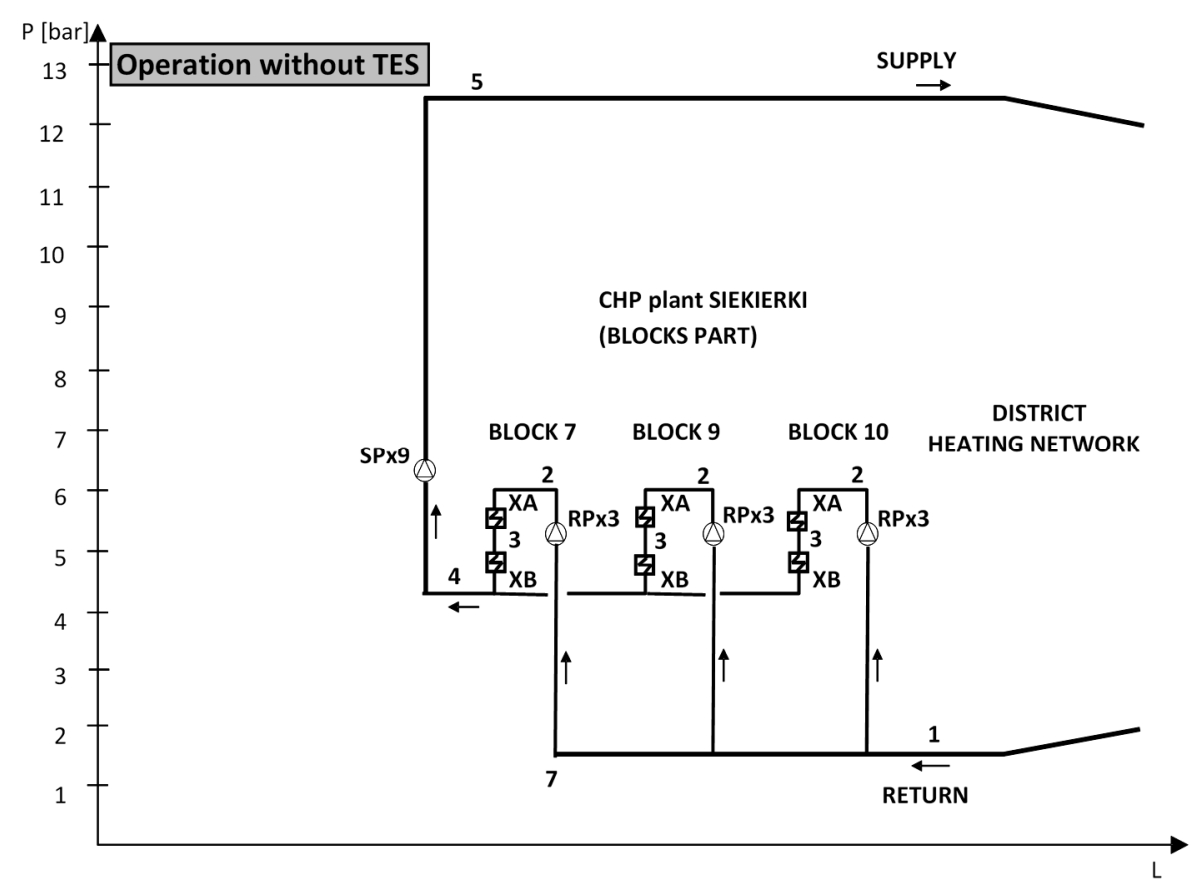

Figure 3. Pressures diagram for the Blocks Part of CHP plant Siekierki (operation without TES).

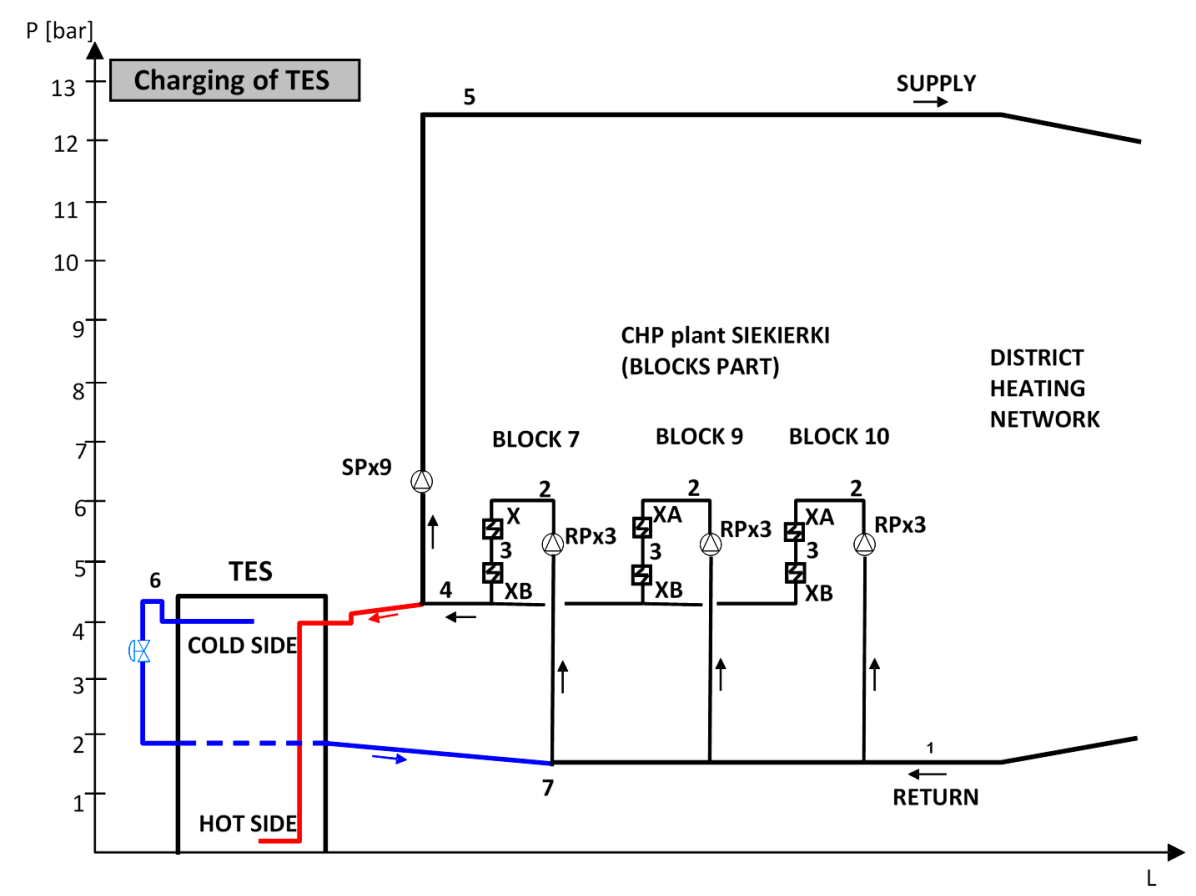

Figure 4. Pressures diagram for the Blocks Part of CHP plant Siekierki during charging of TES. 


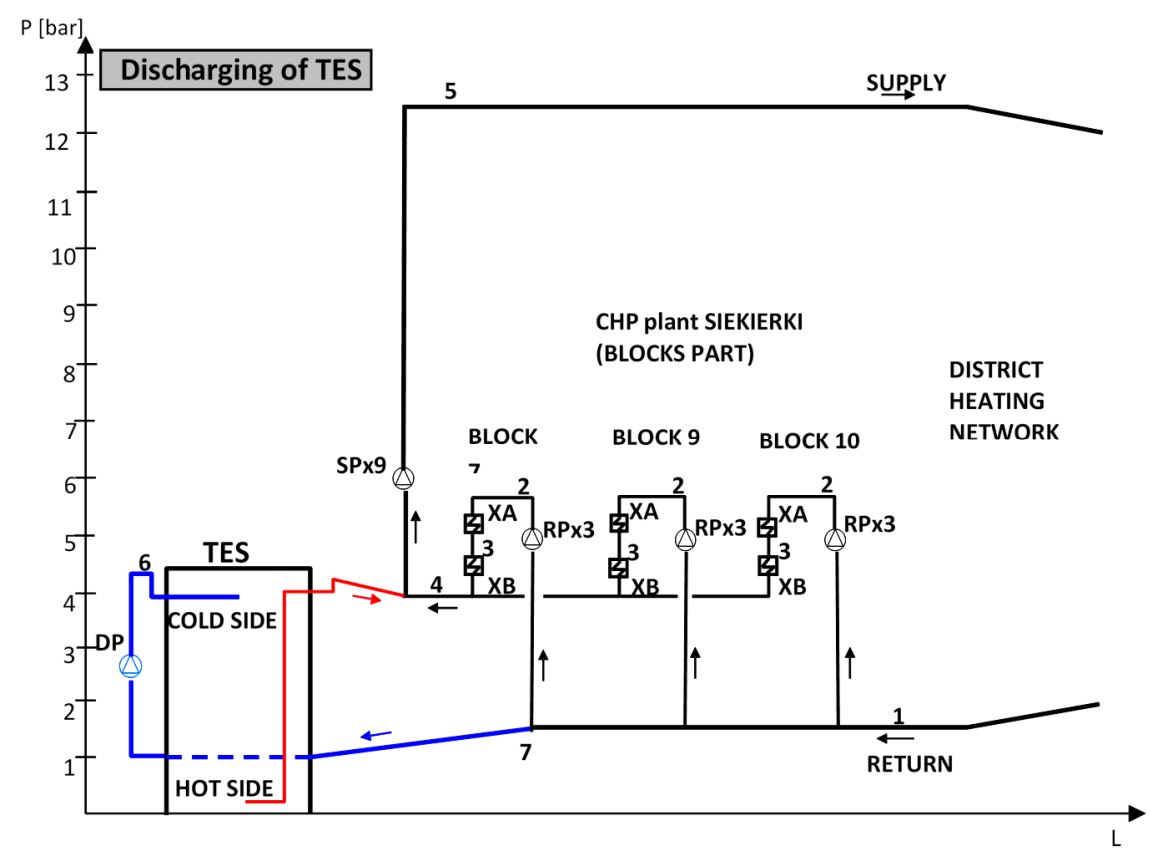

Figure 5. Pressures diagram for the Blocks Part of CHP plant Siekierki during discharging of TES.

\subsection{Energy Analysis}

\subsubsection{CHP Plant Operation without TES}

The pressures diagram for the Blocks Part of the CHP plant Siekierki during operation of the plant without TES is shown in Figure 3. The thermodynamic parameters of water at five points of the system for block numbers 7, 9, and 10 were calculated on the basis of collected operational data of CHP plant (1-before RP pumps, 2-after RP pumps and before XA heat exchanger, 3-after XA and before XB heat exchangers, 4-after XB heat exchanger and before SP pumps, 5-after SP pumps).

The power of the pumps RP and SP and heating capacities of the heat exchangers XA and XB were calculated from following equations for various external air temperatures: $T_{e x}=-20^{\circ} \mathrm{C}, T_{e x}=+1{ }^{\circ} \mathrm{C}$, and $T_{e x}=+15^{\circ} \mathrm{C}$ :

Power for RP pumps ( $\eta=0.8$; three devices) is calculated as:

$$
W_{R P}=\dot{m} \cdot\left(h_{2}-h_{1}\right) / \eta_{R P}
$$

Heating capacity for XA heat exchanger is expressed as:

$$
\dot{Q}_{X A}=\dot{m} \cdot\left(h_{3}-h_{2}\right)
$$

Heating capacity for $\mathrm{XB}$ heat exchanger is stated as:

$$
\dot{Q}_{X B}=\dot{m} \cdot\left(h_{4}-h_{3}\right)
$$

Power of SP pumps ( $\eta=0.82$; three devices $)$ is described as:

$$
W_{S P}=\dot{m} \cdot\left(h_{5}-h_{4}\right) / \eta_{S P}
$$

\subsubsection{CHP Plant Operation with TES-Charging Process of TES}

Figure 4 shows a pressures diagram for the Blocks Part of CHP plant Siekierki during operation of the plant with TES in the course of the charging process of the TES. The thermodynamic parameters of the water at seven points of the system for block numbers 7,9, and 10 were calculated on the basis 
of operational data of the CHP plant collected during the charging process of the TES (1-before RP pumps, 2-after RP pumps and before XA heat exchanger, 3-after XA and before XB heat exchangers, 4-after XB heat exchanger and before SP pumps, 5-after SP pumps, 6-cold side of TES before control valve, 7-cold side of TES after control valve).

The power of the pumps RP and SP and heating capacities of the heat exchangers XA and XB were calculated from the same Equations (1)-(4) as for operation of the plant without TES and also for various external air temperatures: $T_{e x}=-20^{\circ} \mathrm{C}, T_{e x}=1{ }^{\circ} \mathrm{C}$, and $T_{e x}=15^{\circ} \mathrm{C}$

\subsubsection{CHP Plant Operation with TES-Discharging Process of TES}

Figure 5 shows the pressures diagram for the Blocks Part of CHP plant Siekierki during operation of the plant with TES in the course of the discharging process of the TES. The thermodynamic parameters of the water at seven points of the system for block numbers 7,9, and 10 were calculated on the basis of operational data of the CHP plant collected during the discharging process of the TES (1-before RP pumps, 2-after RP pumps and before XA heat exchanger, 3-after XA and before XB heat exchangers, 4-after XB heat exchanger and before SP pumps, 5-after SP pumps, 6-cold side of TES after DP pump, 7-cold side of TES before DP pump).

The power of the pumps RP and SP and heating capacities of the heat exchangers XA and XB were calculated from the same Equations (1)-(4) as for operation of the plant without TES. The power of the DP pumps was calculated from Equation (5). As in previous cases all calculations were performed for various external air temperatures: $T_{e x}=-20^{\circ} \mathrm{C}, T_{e x}=1{ }^{\circ} \mathrm{C}$, and $T_{e x}=15^{\circ} \mathrm{C}$.

Power of TES pumps (DP) is calculated as:

$$
W_{D P}=\dot{m} \cdot\left(h_{6}-h_{7}\right) / \eta_{D P}
$$

\subsection{Exergy Analysis}

Exergy is defined as the maximum amount of work that a thermodynamically open system can do in a given environment by going into equilibrium with the environment. The environment is treated as a reservoir of useless energy and matter at a constant temperature. Maximum energy is obtained in a reversible process [27]. Exergy analysis can be recognized as one of the most important methods for performance evaluations and design calculations of TES systems. It is considered as more powerful than energy analysis [32-35].

In this paper exergy analysis is simplified and neglects exergy destruction for the storing period of the TES. This is related to the fact that the analyzed TES in Warsaw CHP plant has the following construction and operation characteristics:

- the tank insulation is $500 \mathrm{~mm}$ thick (glass wool), therefore heat losses to ambient air are very low,

- the storing periods are short, not usually more than a few hours,

- stratification and thermocline are observed as good and very stable.

The heat losses from the TES tank depend mainly on the thickness of insulation, insulation conductivity, and the heat transfer coefficient [36]. For sensible water TES with a short-term storage period, $500 \mathrm{~mm}$ thickness of insulation is commonly applied. Presently, as insulation material, usually glass wool is preferred due to its low density and thermal conductivity. In case of such insulated water tank, heat losses do not exceed $1-3 \%$ of the total heat stored in the tank as was observed during start-up and commissioning of the TES in the last few years in Poland [31].

Results of analyses presented in $[33,37]$ indicate that for properly designed TES, the storing period is characterized by relatively high exergy efficiencies in excess of $80 \%$.

In order to integrate the heat accumulator into the existing hydraulic system of the CHP plant, new pipelines were added. The length of new pipelines does not exceed $5 \%$ of the length of existing pipelines. Exergy losses in pipelines should be considered as an important element of the balance of 
losses for the entire system, however, due to a slight change in the existing hydraulic system, it was decided to omit these calculations in this study.

As was presented in $[33,38,39]$, the three-zone temperature-distribution models for the TES tank appear to provide sufficient calculation accuracy for exergy contents of vertically stratified TES. Additionally, in this paper [33], a stepped (two-zones) temperature-distribution model was analyzed and the results were compared with a basic three-zone temperature-distribution model. The equivalent temperature of a mixed TES that has the same exergy as the stratified TES was calculated for both of the above-mentioned models. The difference between temperatures computed for those models was less than $1 \%$, therefore for further calculation of exergy destruction for the TES tank, a stepped two-zones model was applied, for reasons of greater simplicity.

\subsubsection{CHP Plant Operation without TES}

For the scheme presented in Figure 3 thermodynamic parameters at specified points of the system for block numbers 7, 9, and 10 were calculated on the basis of collected operational data of the CHP plant without TES [32]. Water and steam parameters were calculated using IF-97 formulas [40].

In pumps, exergy destruction is described by following equation (Gouy-Stodola Theorem) [41]. Due to the fact that the heat transfer in this process is assumed to be zero, the equation takes the form as below:

$$
\dot{\Pi}_{P}=T_{o} \Delta \dot{S}_{P}
$$

The Gouy-Stodola Theorem states that the rate of exergy destruction is proportional to the rate of entropy generation. This destruction is caused by irreversibility and is equal to the ambient temperature multiplied by the sum of the increases in entropy of all components participating in the thermodynamic transformation. The exergy losses calculated according to this equation are additive. The exergy loss described by the Gouy-Stodola Theorem is completely irreversible and cannot even be partially recovered.

Exergy destruction in RP pumps (three devices):

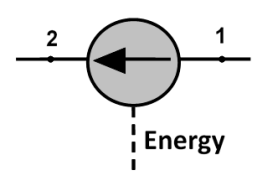

$$
\dot{\Pi}_{R P}=T_{0} \Delta \dot{S}=T_{0} \cdot \dot{m} \cdot\left(s_{2}-s_{1}\right)
$$

Exergy destruction in XA heat exchanger (necessary parameters of medium, i.e., steam, condensate, and water, were calculated for the points shown in the sketch) was calculated as per the procedure shown below.

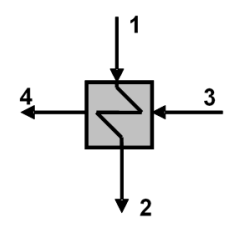

Power of XA heat exchanger:

$$
\dot{Q}_{X A} \text {-given from operational data }
$$

Steam/condensate mass flow:

$$
\dot{m}_{s / c}=\dot{Q}_{X A} /\left(h_{1}^{\prime \prime}-h_{2}^{\prime}\right)
$$


Water mass flow:

$$
\dot{m_{w}} \text { —was given from operational data }
$$

Entropy change:

$$
\Delta \dot{S}_{X A}=\left(\dot{m}_{s / c} \cdot s_{2}+\dot{m}_{w} \cdot s_{4}\right)-\left(\dot{m}_{s / c} \cdot s_{1}+\dot{m}_{w} \cdot s_{3}\right)
$$

Exergy destruction:

$$
\dot{\Pi}_{X A}=T_{0} \Delta \dot{S}_{X A}
$$

Exergy destruction in $\mathrm{XB}$ heat exchanger is calculated in a similar way as for heat exchanger $\mathrm{XA}$ : power of $\mathrm{XB}$ heat exchanger:

$$
\dot{Q}_{X B} \text {-was given from operational data }
$$

Steam/condensate mass flow:

$$
\dot{m}_{s / c}=\dot{Q}_{X B} /\left(h_{1}^{\prime \prime}-h_{2}^{\prime}\right)
$$

Water mass flow:

$$
\dot{m}_{w} \text {-was given from operational data }
$$

Entropy change:

$$
\Delta \dot{S}_{X B}=\left(\dot{m}_{s / c} \cdot s_{2}+\dot{m}_{w} \cdot s_{4}\right)-\left(\dot{m}_{s / c} \cdot s_{1}+\dot{m}_{w} \cdot s_{3}\right)
$$

Exergy destruction:

$$
\dot{\Pi}_{X B}=T_{o} \Delta \dot{S}_{X B}
$$

Exergy destruction in SP pumps (three devices):

$$
\dot{\Pi}_{S P}=T_{0} \Delta \dot{S}=T_{0} \cdot \dot{m} \cdot\left(s_{5}-s_{4}\right)
$$

3.2.2. CHP Plant Operation with TES—Charging Process of TES

Throttling losses during the charging process:

$$
\dot{\Pi}_{t h r}=T_{0} \Delta \dot{S}=T_{0} \cdot \dot{m} \cdot\left(s_{1}-s_{7}\right)
$$

Exergy destruction for TES during the charging process:

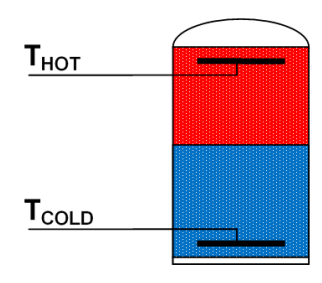

$$
\dot{\Pi}_{T E S}=T_{0} \Delta \dot{S}=T_{0} \cdot \dot{m} \cdot c_{p} \ln \left(T_{H O T} / T_{C O L D}\right)
$$

3.2.3. CHP Plant Operation with TES—Discharging Process of TES

Exergy destruction in TES Discharging Pumps (DP pumps): 


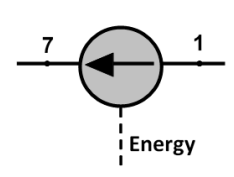

$$
\dot{\Pi}_{D P}=T_{0} \Delta \dot{S}=T_{0} \cdot \dot{m} \cdot\left(s_{7}-s_{1}\right)
$$

Exergy destruction for TES during the discharging process could also be calculated from Equation (20).

\section{Results and Discussion}

Results of the energy analysis for the Blocks Part of the CHP plant are presented in Table 2. This analysis was made for three different operation variants of the CHP plant, i.e., operation without TES, operation with TES - charging process of TES and operation with TES—discharging process of TES. Calculations were performed for three different outside temperatures: $T_{e x}=-20^{\circ} \mathrm{C}, T_{e x}=1{ }^{\circ} \mathrm{C}$, and $T_{e x}=15^{\circ} \mathrm{C}$ for each considered operation variant.

Table 2. Power of appliances for CHP plant operation.

\begin{tabular}{|c|c|c|c|c|c|c|c|c|c|}
\hline \multirow{4}{*}{$\begin{array}{l}\text { Power } \\
(\mathrm{MW})\end{array}$} & \multicolumn{9}{|c|}{ Block No } \\
\hline & \multicolumn{3}{|c|}{7} & \multicolumn{3}{|c|}{9} & \multicolumn{3}{|c|}{10} \\
\hline & \multicolumn{9}{|c|}{$T_{e x}\left({ }^{\circ} \mathrm{C}\right)$} \\
\hline & -20 & 1 & 15 & -20 & 1 & 15 & -20 & 1 & 15 \\
\hline \multicolumn{10}{|c|}{ Operation without TES } \\
\hline RP pumps & 7.9 & 1.4 & 1.2 & 8.3 & 1.4 & - & 2.5 & 1.5 & - \\
\hline XA heat exchanger & 113.6 & 103.7 & 97.6 & 117.0 & 131.0 & - & 117.3 & 94.4 & - \\
\hline XB heat exchanger & 91.4 & 89.8 & 84.9 & 58.6 & 74.0 & - & 75.3 & 96.9 & - \\
\hline SP pumps & 2.6 & 2.4 & 1.5 & 2.7 & 2.0 & - & 3.9 & 2.7 & - \\
\hline \multicolumn{10}{|c|}{ Charging process of TES } \\
\hline RP pumps & 8.1 & 1.4 & 1.2 & 8.8 & 1.2 & - & 2.6 & 1.5 & - \\
\hline XA heat exchanger & 111.2 & 108.9 & 112.5 & 125.0 & 140.5 & - & 113.6 & 101.0 & - \\
\hline XB heat exchanger & 108.9 & 94.7 & 95.1 & 68.5 & 71.0 & - & 78.4 & 91.8 & - \\
\hline SP pumps & 3.0 & 2.5 & 1.6 & 2.8 & 1.8 & - & 2.5 & 2.8 & - \\
\hline \multicolumn{10}{|c|}{ Discharging process of TES } \\
\hline RP pumps & 7.9 & 1.4 & 1.0 & 7.8 & 1.4 & - & 2.6 & 1.5 & - \\
\hline XA heat exchanger & 112.0 & 105.8 & 75.4 & 126.3 & 133.8 & - & 119.9 & 99.6 & - \\
\hline XB heat exchanger & 89.1 & 91.4 & 65.2 & 68.9 & 72.3 & - & 77.3 & 96.0 & - \\
\hline SP pumps & 3.4 & 3.4 & 1.6 & 2.6 & 2.0 & - & 2.9 & 2.9 & - \\
\hline DP pumps & 0.7 & 0.8 & 0.5 & 0.7 & 0.8 & - & 0.7 & 0.8 & - \\
\hline
\end{tabular}

Results of the calculations shown in Table 2 indicate that in all cases, i.e., for each operation variant of the CHP plant and each different outside temperature, TES pumps power is relatively low in comparison to RP and SP pumps power and especially to XA and XB heat exchangers heating capacity.

Figure 6 shows the percentage of pumps power for discharging of TES operation variant and outside temperatures $T_{e x}=-20{ }^{\circ} \mathrm{C}$ alternative. In that case TES pumps power represents only $2 \%$ of pumps total power in the Blocks Part of the CHP plant. 


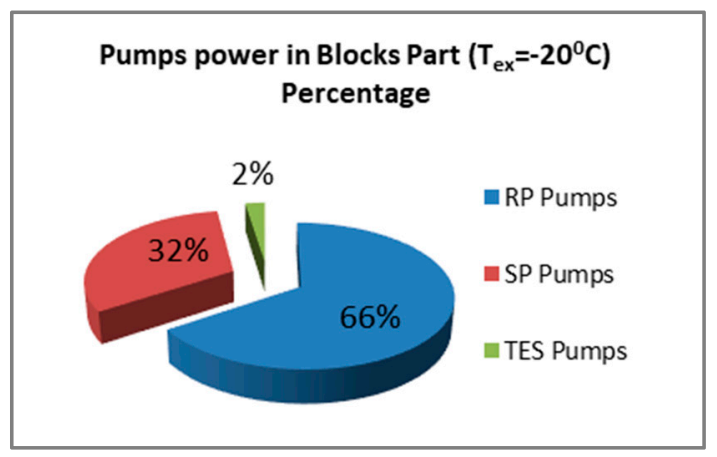

Figure 6. Percentage of pumps power for discharging of TES and temperature $T_{e x}=-20^{\circ} \mathrm{C}$.

Results of the calculation of exergy destructions in the Blocks Part of the CHP plant are presented in Tables 3 and 4. Table 3 contains exergy destructions of RP, SP pumps and XA, XB heat exchangers for block numbers 7,9 , and 10 operating without TES and during the charging and discharging process of TES for different outside temperatures.

Table 3. Exergy destruction in block numbers 7, 9, and 10 for CHP plant operation.

\begin{tabular}{|c|c|c|c|c|c|c|c|c|c|}
\hline \multirow{4}{*}{$\begin{array}{l}\text { Exergy Destruction } \\
\text { (MW) }\end{array}$} & \multicolumn{9}{|c|}{ Block No } \\
\hline & \multicolumn{3}{|c|}{7} & \multicolumn{3}{|c|}{9} & \multicolumn{3}{|c|}{10} \\
\hline & \multicolumn{9}{|c|}{$T_{e x}\left({ }^{\circ} \mathrm{C}\right)$} \\
\hline & -20 & 1 & 15 & -20 & 1 & 15 & -20 & 1 & 15 \\
\hline \multicolumn{10}{|c|}{ Operation without TES } \\
\hline RP pumps & 4.63 & 0.39 & 0.36 & 5.06 & 0.48 & - & 1.10 & 0.52 & - \\
\hline XA heat exchanger & 4.93 & 5.1 & 4.4 & 1.04 & 8.9 & - & 6.97 & 7.09 & - \\
\hline XB heat exchanger & 1.96 & 2.48 & 2.13 & 1.56 & 2.85 & - & 1.77 & 3.95 & - \\
\hline SP pumps & 0.65 & 0.60 & 0.73 & 0.67 & 0.20 & - & 1.22 & 0.48 & - \\
\hline \multicolumn{10}{|c|}{ Charging process of TES } \\
\hline RP pumps & 4.80 & 0.38 & 0.44 & 5.56 & 0.46 & - & 1.10 & 0.48 & - \\
\hline XA heat exchanger & 4.93 & 5.33 & 5.04 & 1.27 & 9.08 & - & 6.97 & 7.78 & - \\
\hline XB heat exchanger & 2.28 & 2.82 & 2.33 & 1.87 & 2.33 & - & 1.77 & 3.57 & - \\
\hline SP pumps & 0.87 & 0.49 & 0.68 & 0.83 & 0.37 & - & 1.22 & 0.84 & - \\
\hline \multicolumn{10}{|c|}{ Discharging process of TES } \\
\hline RP pumps & 4.66 & 0.39 & 0.35 & 4.65 & 0.48 & - & 1.22 & 0.49 & - \\
\hline XA heat exchanger & 5.10 & 5.30 & 3.69 & 1.27 & 8.76 & - & 7.50 & 8.56 & - \\
\hline XB heat exchanger & 2.36 & 2.74 & 1.87 & 0.95 & 2.59 & - & 1.77 & 3.72 & - \\
\hline SP pumps & 0.65 & 0.87 & 0.69 & 0.58 & 0.20 & - & 1.22 & 0.80 & - \\
\hline
\end{tabular}

Table 4. Exergy destruction for operation of the TES system for the Blocks Part of the CHP plant.

\begin{tabular}{cccc}
\hline \multirow{2}{*}{$\begin{array}{c}\text { Exergy Destruction } \\
\text { (MW) }\end{array}$} & \multicolumn{3}{c}{$\boldsymbol{T}_{\boldsymbol{e x}}\left({ }^{\circ} \mathbf{C}\right)$} \\
\cline { 2 - 3 } & \multicolumn{4}{c}{$\mathbf{- 2 0}$} & $\mathbf{+ 1}$ & $\mathbf{+ 1 5}$ \\
\hline \multicolumn{4}{c}{ Charging process of TES } \\
\hline Throttling losses & 0.32 & 0.16 & 0.45 \\
TES charging process & 0.12 & 0.12 & 0.12 \\
\hline \multicolumn{4}{c}{ Discharging process of TES } \\
\hline DP pumps & 0.15 & 0.15 & 0.13 \\
TES discharging process & 0.15 & 0.24 & 0.16 \\
\hline
\end{tabular}


Table 4 covers exergy destructions for the TES system (charging and discharging process) for the Blocks Part of the CHP plant for different outside temperatures.

Figures 7 and 8 present values of exergy destruction in the Blocks Part of the CHP plant, respectively, for the charging and discharging processes of TES and outside temperature $T_{e x}=-20^{\circ} \mathrm{C}$.

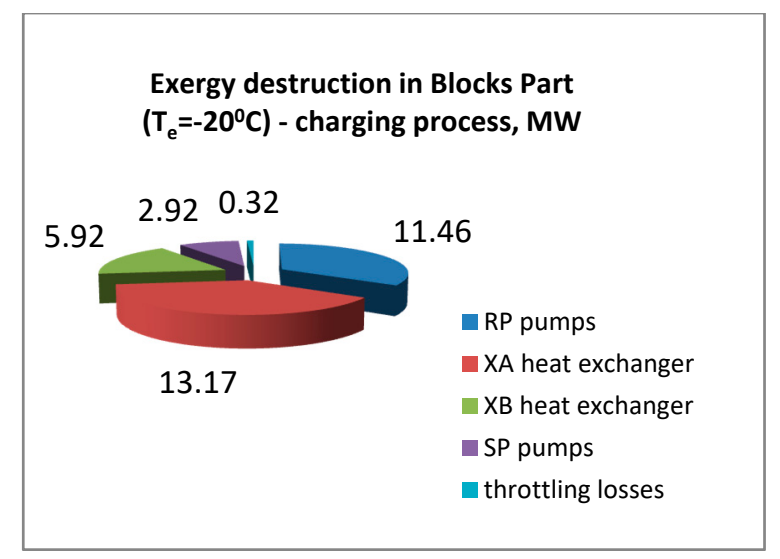

Figure 7. Values of exergy destruction in the Blocks Part of the CHP plant for charging of TES and $T_{e x}=-20^{\circ} \mathrm{C}$.

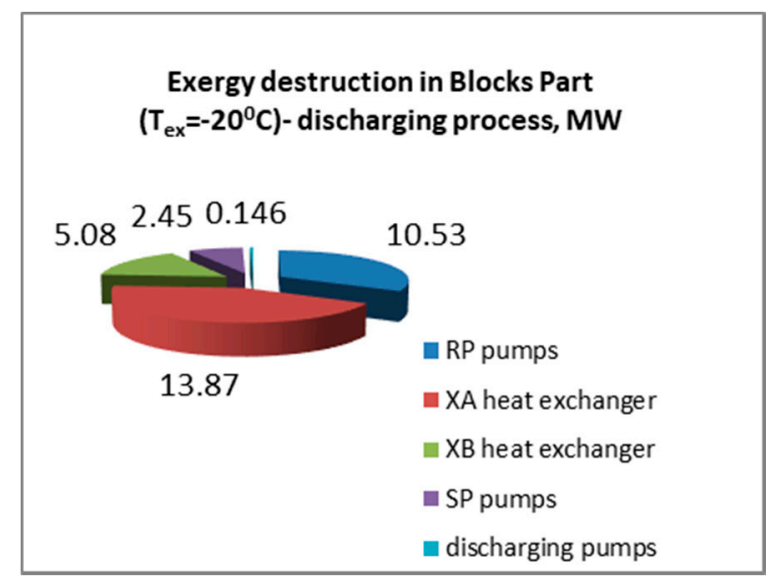

Figure 8. Values of exergy destruction in the Blocks Part of the CHP plant for discharging of TES and $T_{e x}=-20^{\circ} \mathrm{C}$.

\section{Conclusions}

The paper contains a simplified energy and exergy analysis of the hydraulic system integrated with Thermal Energy Storage (TES). The analysis was performed for combined heat and power plant (CHP) supplying heat to the District Heating System (DHS). The energy and exergy analysis was performed for the winter season (the lowest ambient temperature $T_{e x}=-20{ }^{\circ} \mathrm{C}$, i.e., design point conditions), the intermediate season (average ambient temperature $T_{e x}=1^{\circ} \mathrm{C}$ ), and summer (average ambient temperature $T_{e x}=15^{\circ} \mathrm{C}$ ). The presented results of the analysis make it possible to identify the places of the greatest exergy destruction in the pumps and pipelines system with TES, and thus give the opportunity to take necessary improvement actions in further steps. The analysis carried out as part of the article shows that in order to significantly reduce the consumption of electricity and heat in the considered hydraulic system, modernization work should be undertaken in the area of heat exchangers and pumps. In the case of pumps, the possibility of increasing the efficiency of the pumps (e.g., by replacing them with modern ones) and introducing their effective regulation (variable-speed regulation, i.e., introduction of frequency converters, etc.) should be considered. In the case of heat exchangers, replacing them, for example, with heat pumps, however, such an operation will require 
separate analysis and significant investment costs.Detailed results of the energy-exergy analysis show that both the energy consumption and the rate of exergy destruction in relation to the operation of the pumps and pipelines system of the CHP plant with TES for the tank charging and discharging cycles are relatively low, i.e., the power of the additional equipment (discharging pumps DP) is at the level of $0.5-0.8 \mathrm{MW}$ which corresponds to about $0.5-0.8 \%$ of the total power of the block (each block has $110 \mathrm{MW}_{\mathrm{e}}$ ). The exergy destruction is in the range of $0.12-0.45 \mathrm{MW}$.

It should be emphasized that the introduction of a heat accumulation system like TES does not significantly increase energy losses and exergy destruction in the analyzed cases, so this type of investment will not significantly increase the consumption of electricity (pumps) and heat (heat exchangers and TES). Obviously, the amounts of energy and exergy losses differ significantly for different ambient temperatures, i.e., CHP plant operation in winter, intermediate, and summer periods, but the percentage of these losses is practically constant.

Detailed conclusions resulting from energy and exergy analysis could be expressed as follows:

- Power of the TES pumps is relatively low in relation to the power of the block and is approx. $500-800 \mathrm{~kW}$, which equates to approx. $0.5-0.8 \%$ of the block electric power.

- For the lowest considered outside temperature $T_{e x}=-20{ }^{\circ} \mathrm{C}$ TES pumps power represents only $2 \%$ of pumps total power in the Blocks Part of the CHP plant.

- Differences in powers and losses of the RP and SP pumps are negligible during operation of the CHP plant without and with the TES.

- The biggest exergy destruction appears in the heat exchangers, but the differences between them for the analyzed cases, i.e., during operation of the Blocks Part of CHP plant without the TES and the charging and discharging processes of the TES, are negligible.

- Throttling losses during the charging process of the TES and exergy destruction in Discharging Pumps (TES Pumps) are also low and fluctuate in the range $120-450 \mathrm{~kW}$ depending on the considered case.

A simplified energy and exergy analysis was also carried out for CHP plants with technologically similar TES systems, i.e., CHP plant in Białystok and CHP plant in Bielsko Biała. CHP plant in Bialystok is equipped with a TES with a capacity of $12,800 \mathrm{~m}^{3}$, while CHP plant in Bielsko Biała with a TES with a capacity of $21,450 \mathrm{~m}^{3}$ [29]. The results of the analysis indicate that the percentages of energy losses and exergy destruction for heat exchangers, pumps and TES tanks are analogous to those presented in this paper.

Author Contributions: Conceptualization, R.Z. and M.W.; methodology, R.Z. and M.W.; software, M.W.; validation, R.Z. and M.W.; formal analysis, R.Z.; investigation, R.Z. and M.W.; resources, R.Z.; data curation, M.W.; writing-original draft preparation, R.Z. and M.W.; writing-review and editing, R.Z. and M.W.; visualization, R.Z. and M.W.; supervision, R.Z.; project administration, M.W.; funding acquisition, M.W. All authors have read and agreed to the published version of the manuscript.

Funding: This research received no external funding.

Conflicts of Interest: The authors declare no conflict of interest.

\section{Nomenclature}

$\begin{array}{ll}c_{p} & \text { specific heat capacity }(\mathrm{kJ} / \mathrm{kg} \cdot \mathrm{K}) \\ h & \text { specific enthalpy }(\mathrm{kJ} / \mathrm{kg}) \\ m & \text { mass }(\mathrm{kg}) \\ \dot{m} & \text { mass flow rate }(\mathrm{kg} / \mathrm{s}) \\ p & \text { pressure }(\mathrm{bar}) \\ \dot{Q} & \text { heat rate }(\mathrm{kW}) \\ s & \text { specific entropy }(\mathrm{kJ} / \mathrm{kg} \cdot \mathrm{K}) \\ \dot{S} & \text { entropy rate }(\mathrm{kW} / \mathrm{K}) \\ T & \text { temperature }\left({ }^{\circ} \mathrm{C} \text { or } \mathrm{K}\right) \\ W & \text { power }(\mathrm{kW} \text { or } \mathrm{MW})\end{array}$




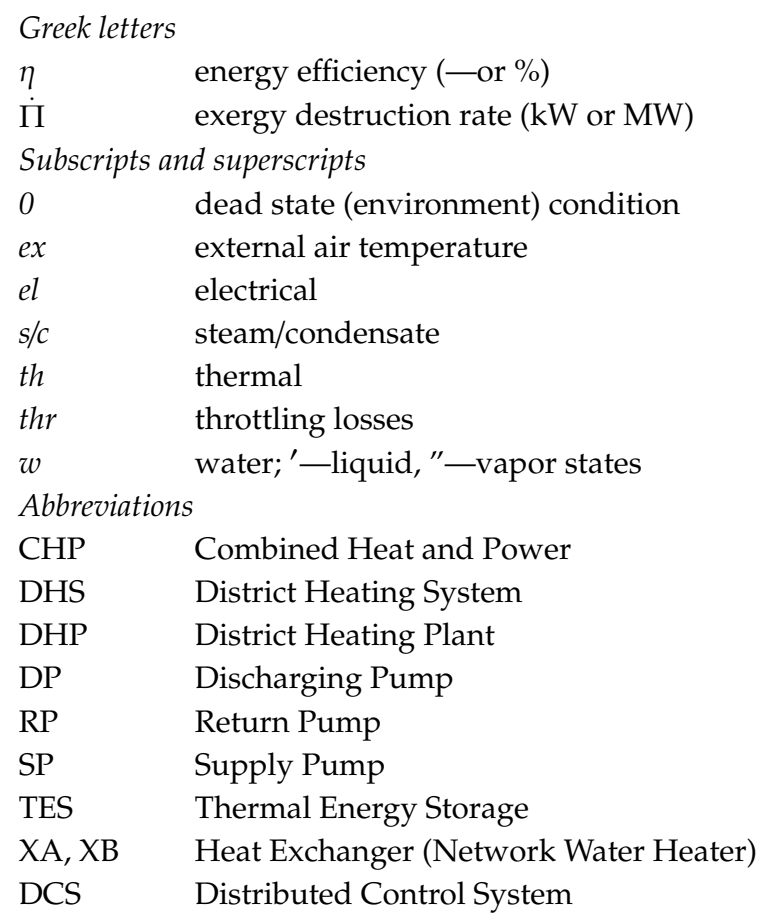

\section{References}

1. The Carbon Trust. Biomass Heating; A Practical Guide for Potential Users; The Carbon Trust: London, UK, 2005.

2. Obernberger, I. Decentralized biomass combustion: State of the art and future development. Biomass Bioenergy 1998, 14, 33-56. [CrossRef]

3. Fernández, R.G.; García, C.P.; Lavín, A.G.; Bueno De Las Heras, J.L. Study of main combustion characteristics for biomass fuels used in boilers. Fuel Process. Technol. 2012, 103, 16-26. [CrossRef]

4. Ürge-Vorsatz, D.; Cabeza, L.F.; Serrano, S.; Barreneche, C.; Petrichenko, K. Heating and cooling energy trends and drivers in buildings. Renew. Sustain. Energy Rev. 2015, 41, 85-98. [CrossRef]

5. Onovwiona, H.I.; Ugursal, V.I. Residential cogeneration systems: Review of the current technology. Renew. Sustain. Energy Rev. 2006, 10, 389-431. [CrossRef]

6. Chel, A.; Kaushik, G. Renewable energy technologies for sustainable development of energy efficient building. Alex. Eng. J. 2018, 57, 655-669. [CrossRef]

7. Chan, H.Y.; Riffat, S.B.; Zhu, J. Review of passive solar heating and cooling technologies. Renew. Sustain. Energy Rev. 2010, 14, 781-789. [CrossRef]

8. Tyagi, V.V.; Kaushik, S.C.; Tyagi, S.K. Advancement in solar photovoltaic/thermal (PV/T) hybrid collector technology. Renew. Sustain. Energy Rev. 2012, 16, 1383-1398. [CrossRef]

9. Pająk, L.; Tomaszewska, B.; Bujakowski, W.; Bielec, B.; Dendys, M. Review of the low-enthalpy lower cretaceous geothermal energy resources in poland as an environmentally friendly source of heat for urban district heating systems. Energies 2020, 13, 1302. [CrossRef]

10. Bundschuh, J.; Tomaszewska, B.; Ghaffour, N.; Hamawand, I.; Mahmoudi, H.; Goosen, M. Coupling geothermal direct heat with agriculture. In Geothermal Water Management; CRC Press: Boca Raton, FL, USA, 2018; pp. 277-300. ISBN 9781317562580.

11. Bujakowski, W.; Tomaszewska, B.; Miecznik, M. The Podhale geothermal reservoir simulation for long-term sustainable production. Renew. Energy 2016, 99, 420-430. [CrossRef]

12. Tomaszewska, B.; Szczepański, A. Possibilities for the efficient utilisation of spent geothermal waters. Environ. Sci. Pollut. Res. 2014, 21, 11409-11417. [CrossRef]

13. Tomaszewska, B.; Sowiżdżał, A.; Chmielowska, A. Selected technical aspects of well construction for geothermal energy utilization in Poland. Contemp. Trends Geosci. 2018, 7, 188-199. [CrossRef]

14. Tomaszewska, B.; Pajak, L. Gospodarka zasobami wód termalnych—Ekonomiczne aspekty ich uzdatniania. Gospod. Surowcami Miner. Miner. Resour. Manag. 2012, 28, 59-70. [CrossRef] 
15. Lund, H.; Andersen, A.N. Optimal designs of small CHP plants in a market with fluctuating electricity prices. Energy Convers. Manag. 2005, 46, 893-904. [CrossRef]

16. Hedman, B.; Kaarsberg, T. Combined heat and power (CHP). In Distributed Generation: The Power Paradigm for the New Millennium; Borbely, A.M., Kreider, J.F., Eds.; CRC Press: Boca Raton, FL, USA, 2001; pp. $271-294$. ISBN 9781420042399.

17. Ren, H.; Gao, W.; Ruan, Y. Optimal sizing for residential CHP system. Appl. Therm. Eng. 2008, 28, 514-523. [CrossRef]

18. Lund, R.; Mathiesen, B.V. Large combined heat and power plants in sustainable energy systems. Appl. Energy 2015, 142, 389-395. [CrossRef]

19. Gvozdenac, D.; Urošević, B.G.; Menke, C.; Urošević, D.; Bangviwat, A. High efficiency cogeneration: CHP and non-CHP energy. Energy 2017, 135, 269-278. [CrossRef]

20. Connolly, D.; Lund, H.; Mathiesen, B.V.; Werner, S.; Möller, B.; Persson, U.; Boermans, T.; Trier, D.; Østergaard, P.A.; Nielsen, S. Heat roadmap Europe: Combining district heating with heat savings to decarbonise the EU energy system. Energy Policy 2014, 65, 475-489. [CrossRef]

21. Rezaie, B.; Rosen, M.A. District heating and cooling: Review of technology and potential enhancements. Appl. Energy 2012, 93, 2-10. [CrossRef]

22. Werner, S. District heating and cooling in Sweden. Energy 2017, 126, 419-429. [CrossRef]

23. Werner, S. International review of district heating and cooling. Energy 2017, 137, 617-631. [CrossRef]

24. IEA-International Energy Agency. Technology Roadmap—Energy Storage. Available online: https//www. iea.org/reports/technology-roadmap-energy-storage (accessed on 5 August 2020).

25. Caliskan, H.; Dincer, I.; Hepbasli, A. Energy and exergy analyses of combined thermochemical and sensible thermal energy storage systems for building heating applications. Energy Build. 2012, 48, 103-111. [CrossRef]

26. Zwierzchowski, R. Improvement of operation of steam cushion system for sensible thermal energy storage. In Proceedings of the International Conference on Advances in Energy Systems and Environmental Engineering (ASEE19), Wroclaw, Poland, 9-12 June 2019.

27. Dincer, I. On thermal energy storage systems and applications in buildings. Energy Build. 2002, 34, 377-388. [CrossRef]

28. Dincer, I. Thermal energy storage systems as a key technology in energy conservation. Int. J. Energy Res. 2002, 26, 567-588. [CrossRef]

29. Zwierzchowski, R. Characteristics of large thermal energy storage systems in Poland. In Proceedings of the International Conference on Advances in Energy Systems and Environmental Engineering (ASEE17), Wroclaw, Poland, 2-5 July 2017.

30. Dincer, I.; Dost, S.; Li, X. Thermal energy storage applications from an energy saving perspective. Int. J. Glob. Energy Issues 1997, 9, 351-364. [CrossRef]

31. Zwierzchowski, R. Analiza Układów Hydraulicznych w Elektrociepłowniach i Ciepłowniach z Akumulatorem Ciepła; Oficyna Wydawnicza Politechniki Warszawskiej: Warsaw, Poland, 2013.

32. Dincer, I.; Dost, S.; Li, X. Performance analyses of sensible heat storage systems for thermal applications. Int. J. Energy Res. 1997, 21, 1157-1171. [CrossRef]

33. Dinçer, I.; Rosen, M.A. Thermal Energy Storage: Systems and Applications, 2nd ed.; John Wiley \& Sons: Hoboken, NJ, USA, 2010; ISBN 9780470747063.

34. Rosen, M.A.; Dincer, I. Exergy methods for assessing and comparing thermal storage systems. Int. J. Energy Res. 2003, 27, 415-430. [CrossRef]

35. Krane, R.J. A Second Law analysis of the optimum design and operation of thermal energy storage systems. Int. J. Heat Mass Transf. 1987, 30, 43-57. [CrossRef]

36. Jurigova, M.; Chmúrny, I. Systems of Sensible Thermal Energy Storage. Appl. Mech. Mater. 2016, 820, 206-211. [CrossRef]

37. Rosen, M.A. Appropriate thermodynamic performance measures for closed systems for thermal energy storage. J. Sol. Energy Eng. Trans. ASME 1992, 114, 100-105. [CrossRef]

38. Rosen, M.; Hooper, F. Designer-oriented temperature distribution models for vertically stratified thermal energy storages to facilitate energy and exergy evaluation. In Proceedings of the 6th International Conference on Thermal Energy Storages, Espoo, Finland, 22-25 August 1994; pp. 263-270.

39. Rosen, M.A.; Tang, R.; Dincer, I. Effect of stratification on energy and exergy capacities in thermal storage systems. Int. J. Energy Res. 2004, 28, 177-193. [CrossRef] 
40. Wagner, W.; Kretzschmar, H.J. IAPWS Industrial Formulation 1997 for the Thermodynamic Properties of Water and Steam. In International Steam Tables; Springer: Berlin/Heidelberg, Germany, 2008; pp. 7-150.

41. Bejan, A. Exergy analysis of thermal, chemical and metallurgical processes. Int. J. Heat Fluid Flow 1989, 10, 87-88. [CrossRef] 